\title{
LINEAR PROGRAMMING MODEL TO OPTIMIZE THE WATER RESOURCE USE IN IRRIGATION PROJECTS: AN APPLICATION TO THE SENATOR NILO COELHO PROJECT
}

\author{
J.A. FRIZZONE ${ }^{1,4}$; R.D. COELHO'; D. DOURADO-NETO ${ }^{2,4}$; R. SOLIANT \\ 'Depto de Engenharia Rural-ESALQTSSP, C.P. 9, CEP: 13418-900-Piracicaba, SP - Brazil \\ ${ }^{2}$ Depto. de Agricultura-ESALONSP, C.P. 9, CEP: 13418-900 - Piracicaba, SP - Brazil \\ ${ }^{3}$ Depto de Constructio Civil-FECNNICAMP, CEP: 13083-970 - Campinas, SP - Brazil. \\ Bolsista do CNPq
}

SUMMARY: The main objective of this paper was to develop a separable linear programming model, considering a set of technical factors which may infuence the proft of an irrigation project. The modri presents an objective function that maxmizes the net income and specifies the range of water availability. It is assurned that yield functions in response to water application are available for differents crops and describe very well the water-yield relationships. The linear programming model was developed generically, so that, the rational use of the available water resource conld be included in an irrigation project. Specific equations were developed and applied in the irrigation project "Senator Nilo Coelho" (SNCP), locited in Petrolina - Bravil. Based on the water-yield functions considered, cultivated land constraints, production costs and products prices, it was concladed that: (a) the model was suitable for the management of the SNCP, resulting in optimal cropplng patterns and showing the water requirements; (b) for 7,424 ha of land and $66,644,500 \mathrm{~m}^{3}$ of water avallable on year basis, the shadow price of these resources were respectively, USS $1,115.20 /$ ha e USS $281.60 / 1000 \mathrm{~m}^{3}$; (c) for the total monthly water avallabllity of $9,861,040 \mathrm{~m}^{3}$, the total annual water avallability of $66,644,500 \mathrm{~m}^{3}$ became an effective restriction to the increase of the net income of the production system in the SNCP; (d) maintaining the total monthly water avallability of $9,861,040 \mathrm{~m}^{3}$, annual volumes lower than 88,338,983 $\mathrm{m}^{3}$ were used fully to reach the optimal solution, and that higher volumes than this limit did not increase the net return; (e) the optinization model presented, estimated a net return of $52.34 \%$ higher than the traditional cropping pattern used in the SNCP, considering the agrieultural year of 1992.

Key Words: irrigation, linear programming model

\section{MODELO DE PROGRAMAÇÃo LINEAR PARA OTIMIZAR O USO DA ÁGUA EM PROJETOS DE IRRIGAÇÃO: UMA APLICAÇÃO AO PROJETO SENADOR NILO COELHO}

RESUMO: O objettvo deste trabalho fol desenvolver um modelo de programacio linear separivel, que considera um conjunto de fatores técnicos que influencia a rentablidade de un projeto de irrigaç̄o. 0 modelo tem como funçáo objetivo a máxima receita liquida. Assume-se que as funçöes de resposta das culturas $\mathbf{i}$ imigaç̄o estă̄o disponiveis e representam adequadamentre is relaçōes dgua-produç̄o. O modelo de programaço linear separável foi equaciomado genericamente, de forma a indicar o uso racional do recurso hidrico num projeto de irrigaç̃o e foram desenvolvidas equaçós especificas e aplicadas a um caso, envolvendo o Projeto de Irrigaço Senador Nilo Coelho (PSNC), localizado em Petrolina - PE. Com base nas culturas consideradas e suas respectivas funcóes de resposta à agua, nas restriçses de água e área cultivada, nos preços e nos custos de produçio, os resultados permitiram as seguintes conclusses: (a)o modelo de programagia linear posulbllitou a obtençäo de planos ótimos de cultivo e a correspondente alocaç̄o de água, podendo ser facilmente adaptado a diferentes situagöes do meio fisico; (b) para 7.424 ha de term dlsponiveis e $66.644 .500 \mathrm{~m}^{3}$ anual de frua, o preço sombra destes recursos fol, respectivamente, USS1.115,20/ha e USS $281,60 / 1000 \mathrm{~m}^{3}$, com validade entre $5.619,8$ ha e $8.337,6$ ha e $48.579 .700 \mathrm{~m}^{3}$ e $82.819 .700 \mathrm{~m}^{3}$; (c) para uma disponibilidade mensal de agua de $9.861 .040 \mathrm{~m}^{3}$, disponibilidade anual de $66.644 .500 \mathrm{~m}^{3}$ constitui a restriç̆̃o efettva so aumento da receita liquida no sistema de produço do PSNC; (d) mantendo-se o volume mensal disponivel em $9.861 .040 \mathrm{~m}^{3}$, volumes anuais inferiores $a 88.338 .983 \mathrm{~m}^{3}$ foram utilizados plenamente pelas atividades na soluço 6tima e, volumes superiores a este apresentam folga, máo contribuindo para o aumento da receita líquida (e) o modelo de otimizactio desenvolvido projeton uma receita híquida $52,34 \%$ maior que a obtida com o plano de culttvo tradicional do PSNC, considerado, como exemplo, o ano agricola de 1992.

Descritores: irrigacto, programacko linear 


\section{INTRODUCTION}

To plan the water supply and distribution in an irrigation project, in relation to the production level and to the water needs, the following items must be considered: seasonal and monthly needs of water supply, crop production, crop selection, exploration models and water supply scheduling during growth period.

To optimize his decision, the farmer must choose among the available production alternatives, the most efficient in the use of productive resources and the one which satisfies the previously-stated goals. In the cases where the decision is related to the allocation of scarce resources, the farmer's responsibility is to find efficient methods that can help him to make the right decision. To solve this problem, the mathematical programming models are the most recommended.

The mathematical programming quantifies an optimal way of combining scarce resources to satisfy the proposed goals, that is , they analyze the cases where the available resources must be combined in a way to maximize the profit or minimize the cost.

The profit maximization in an irrigated area can be favored practicing irrigation with water deficit, also called partial irrigation. This statement can be supported by the economical theory and papers published by several authors (Kumar \& Khepar, 1980; English \& Nuss, 1982; Hargreaves \& Samani, 1984; Dantas Neto, 1994 and Paz, 1995). Doorenbos \& Kassam (1979) say that, when the water supply is limited, the considerations about crop and irrigated area selection must be based on crop profitability according to the effect caused when the water needs are answered by the available water supply during the crop cycle.

According to engineering, to plan irrigation with a deficit is very complex, because it is necessary to trust the production functions. The uncertainity of those functions spoils the precise production prediction as well as the most economical water level (English, 1990), although deficit irrigation is a concept that can be applied with great success. Many farmers who have shortage of available water resources can practice deficit irrigation aiming to maximize the profit, many times in an empirical way.
Several researchers proposed (PalaciosVelez, 1976; Doorenbos \& Kassan, 1979; Kumar \& Khepar, 1980; Vaux Jr. \& Pruitt, 1983 and Mannocchi \& Mecarelli, 1994) that in the case of irrigation in areas where the water availability is a limiting factor to production, the planning problems and available water resource management must be solved estimating the irrigation need of different soil/plant systems taking in account an adequate cropping pattern.

The planning of an irrigation project is considered optimal, according to economical values, if the results maximize the difference between the gross income and the production costs to specific restrictions imposed to the production system. Analyzing the relation between gross income and costs, this problem can be rationally solved by a mathematical programming model.

In this paper, it is assumed that the production functions are available and they represent water/production relations properly. These functions are incorporated to a separated linear programming model that considers a group of technical factors which have influence upon profitability of an irrigation project. It is necessary to equalize the model to indicate the rational use of water resource in an irrigation project. For application, specific equations involving the Senator "Nilo Coelho" Project, in Petrolina, Pernambuco State/Brazil were developed.

\section{MATERIAL AND METHODS}

Model development: The objective function was specified as the net income maximization resulted from several crops subjected to the restrictions of water availability and cropping area.

The gross income by area unit was determined as being proportional to the production, while the costs were taken from a fixed component (production costs not associated to the irrigation depth) and a variable component dependent of the seasonal irrigation depth according to Hart et al. (1980), English (1990) and Mannocchi \& Mecarelli (1994). The gross income was expressed as shown below.

$$
\mathbf{I B}=\sum_{j=1}^{n} \mathbf{P}_{\mathbf{l}} \mathbf{X}_{\mathbf{i}} \mathbf{Y}_{\mathbf{i}}(\mathbf{W})
$$


where, $\mathbf{I B}=$ gross income obtained by $\mathbf{n}$ crops in an $\mathbf{X}$ area, in US\$; $\mathbf{P}_{\mathbf{1}}=$ sale price of the crop product $i$, in USS ha $^{-1} ; Y_{1}(W)=$ crop production $i$ in function of the irrigation depth, in $\mathrm{kg} \cdot \mathrm{ha}^{-1}$; $\mathbf{X}_{\mathbf{i}}=$ cropped and irrigated area with crop $\mathbf{i}$, in ha; and $\mathbf{i}=$ an integer pertaining to the $\operatorname{crop}(1,2, \ldots$, n).

Considering water as the unique variable factor, to the technical unity the production cost was represented:

$$
C P_{1}=C_{1}+C_{w} w_{i}
$$

or, to the economical unity:

$$
C P=\sum_{i=1}^{n} C_{i} x_{i}+\sum_{i=1}^{n} C_{w} w_{i} x_{i}
$$

where, $\mathbf{C P}=$ production cost of the farm, in US\$; $\mathbf{C}_{\mathrm{w}}=$ irrigated water cost, in USS. $\mathrm{mm}^{-1} \cdot \mathrm{ha}^{-1} ; \mathbf{W}_{\mathbf{1}}=$ seasonal irrigation depth, applied to the culture $i$, in $\mathrm{mm}$; and $\mathbf{C}_{\mathbf{l}}=$ crop production costs of crop $\mathbf{i}$, not directly related to the irrigation depth, in US\$.ha' ${ }^{-1}$.

The objective function of the economical unity was formulated as shown below.

$$
\begin{aligned}
& \operatorname{Max} Z=\sum_{i=1}^{\infty} P_{i} Y_{i}(W) X_{i}- \\
& -\sum_{i=1}^{\infty} C_{i} X_{i}-\sum_{i=1}^{\infty} C_{w} X_{i} W_{i}
\end{aligned}
$$

where, $Z$ = net income of the farm resulting from $n$ crops with irrigation depth $W_{1}$, in USS.

The restrictions to what the objective function is subjected to are generally expressed as shown below:

$$
\begin{gathered}
\sum_{l=1}^{n} w_{i} x_{l} \leq V_{a} \\
\sum_{j=1}^{n} a_{i j} x_{l} \leq A_{j}, \text { for } j=1,2, \ldots, J \\
x_{l} \geq 0
\end{gathered}
$$

where, $V_{a}=$ annual volume of available water, in mm.ha; $a_{\text {y }}=$ amount of input $\mathbf{j}$, by unit of area necessary to crops; and $\mathbf{A}_{\mathbf{J}}=$ maximum availability of input $\mathbf{j}$.

This model is a problem of non linear programming because the objective function has a non linear function [Y(W)]. This function can be linearized through the part-linearization technique and the model treated as a problem of separated linear programming (McMillan Jr., 1970).

The model of separated linear programming is developed approaching the non linear functions of crop answers for piecewise linear functions, enabling the "simplex method" to find the solution. The answer function is divided in $k$ linear segments, where $k$ is an integer $(\mathbf{k}=1,2, \ldots, \mathbf{s})$.

If two reference points are considered: $\left(\mathbf{Y}_{\mathbf{1 0}}, \mathbf{W}_{\mathbf{1 0}}\right)$ representing the maximum productivity and the corresponding irrigation depth and $\left(\mathbf{Y}_{\mathrm{k}}\right.$, $W_{1 s}$ ) representing the minimum productivity and the corresponding irrigation depth, a reduction in the irrigation depth of the crop $i$ from $W_{10}$ to $W_{11}$ $\left(\Delta W_{11}\right)$ implies a productivity reduction from $Y_{10}$ to $Y_{11}\left(\Delta Y_{11}\right)$; a reduction from $W_{11}$ to $W_{12}\left(\Delta W_{12}\right)$ results in $Y_{11}$ to $Y_{12}\left(\Delta Y_{12}\right)$ and this way successively. Generally, a reduction in the irrigation depth from $W_{1 k-1}$ to $W_{\text {ik }}\left(\Delta W_{\text {ik }}\right)$ results in a productivity reduction from $Y_{1} k_{k-1}$ to $Y_{1 k}$ $\left(\Delta \mathbf{Y}_{\mathbf{k}}\right)$

The region between $Y_{10}$ and $Y_{t s}$ is the rational zone for resource allocation. It starts from a point where the average product/unit of resource is maximum and ends at the point where the maximum product is attained. The irrigation depth most be selected somewhere between $\mathbf{s}$ and zero, where marginal water productivity is equal to its price.

The model represented by the equations (4), (5), (6) and (7) will be modified here taking into account the linear answer functions by parts to $\mathbf{n}$ crops. Considering that all crops are irrigated with a depth to obtain maximum productivity $\left(\mathbf{W}_{\mathbf{w}}\right)$ to an $\mathbf{X}$ area, the following gross income function can be obtained:

$$
\mathrm{IB}_{0}=\sum_{1=1}^{\infty} \mathbf{X}_{10} \mathbf{Y}_{10} \mathrm{P}_{\mathbf{1}}
$$

where $\mathbf{I B}_{\mathbf{0}}$ is the gross income obtained with $\mathbf{n}$ irrigated crops with depth $\mathbf{W}_{0}$, in US\$. 
The reduction of the irrigation depth from $W_{10}$ to $W_{11}\left(\Delta W_{11}\right)$ implies in the reduction of the gross income of the crop i from $\mathbf{I B}_{1}$ to $\mathbf{I B}_{\mathbf{1 1}}$ $\left(\Delta \mathbf{B}_{11}\right)$. In the same way, a depth reduction from $W_{11}$ to $W_{12}\left(\Delta W_{12}\right)$ results in the reduction of the gross income from $\mathbb{I B}_{11}$ to $\mathbf{B}_{12}\left(\Delta \mathrm{Ib}_{12}\right)$, and so on. To any I crop, the total reduction of the gross income until a $k$ point will be:

$$
\Delta \mathbf{B B}_{\mathbf{k}}=\sum_{\mathbf{k}=1}^{\infty} \Delta \mathbf{B B}_{\mathbf{k}}
$$

Considering $n$ crops where each one gives $\Delta \mathbf{I B}_{1 \mathbf{k}}$, the following can be observed:

$$
\Delta \mathbf{I B}=\sum_{\mathbf{l}=1}^{\infty} \sum_{k=1}^{3} \Delta \mathbf{I B}_{\mathbf{i k}}
$$

Assuming that there is no variation in the total area available for irrigated cropping when the irrigation depth is varied and only the productivity of the crop can vary, for $n$ cultures the equation below can be drawn:

$$
\Delta \mathrm{IB}=\sum_{k=1}^{+} \sum_{k=1}^{\infty} \mathbf{x}_{\mathrm{k}} \Delta \mathbf{Y}_{\mathbf{k}} \mathbf{P}_{\mathrm{i}}
$$

The gross income of the economical unity from $n$ crops using an irrigation depth $\mathbf{W}_{\mathbf{m}}$ lower than $W_{m}$, it can be expressed as shown below:

$$
\begin{aligned}
& I_{k}=\sum_{k=1}^{m} X_{10} Y_{10} P_{1}- \\
& -\sum_{k=1}^{\infty} \sum_{k=1}^{\infty} X_{1 k} \Delta Y_{1 k} P_{1}
\end{aligned}
$$

For an irrigation depth $W_{10}$ and area $X_{10}$, the crop production cost $i$, related to the irrigation depth, can be expressed as:

$$
C P_{10}=C_{i} x_{10}+C_{w} x_{10} W_{10}
$$

Therefore, for $n$ crops result the following equation:

$$
C P_{0}=\sum_{i=1}^{n} c_{1} x_{0}+\sum_{i=0}^{n} c_{w} w_{10} x_{10}
$$

The reduction of the irrigation depth from $W_{10}$ to $W_{11}\left(\Delta W_{11}\right)$ brings a cost reduction from $\mathrm{CP}_{\mathbf{b}}$ to $\mathrm{CP}_{11}\left(\Delta \mathbf{C P}_{11}\right)$, and so on. The cost reduction comes only from the water cost. For an unit area, it can be observed :

$$
\begin{gathered}
\Delta C P_{11}=C_{w}\left(W_{10}-W_{11}\right)=C_{w} \Delta W_{11} \\
\Delta C P_{12}=C_{w}\left(W_{11}-W_{12}\right)=C_{w} \Delta W_{12} \\
\vdots \\
\Delta C P_{1 k}=C_{w}\left(W_{1 k-1}-W_{1 k}\right)=C_{w} \Delta W_{1 k}
\end{gathered}
$$

For $n$ crops and $k$ segments in the production function, the production cost using the irrigation depth $\mathbf{W}_{\mathbf{k}}$, can be formulated as:

$$
\begin{aligned}
C P= & \sum_{k=1}^{n} C_{1} x_{10}+\sum_{i=1}^{n} C_{w} x_{10} W_{10}- \\
& -\sum_{k=1}^{n} \sum_{k=1}^{\infty} C_{w} \Delta W_{1 k} x_{1 k}
\end{aligned}
$$

The net income obtained for $\mathbf{n}$ crops in an $X$ area, irrigated with the water depth $W_{k}$, will be:

$$
\begin{aligned}
& Z=\left(\sum_{i=1}^{n} X_{i 0} Y_{i 0}-\sum_{i=1}^{n} \sum_{k=1}^{s} X_{i k} \Delta Y_{i k}\right) P_{i}- \\
& -\left(\sum_{i=1}^{n} C_{i} X_{i 0}+\sum_{i=1}^{n} C_{i} X_{i 0} W_{i 0}-\right. \\
& \left.-\sum_{i=1}^{n} \sum_{k=1}^{s} C_{i v} \Delta W_{i k} X_{i k}-\right)
\end{aligned}
$$

The aim of the economical unity is to maximize the net income function $(Z)$. This maximization was set up following the restrictions below:

(a) the water volume consumed in the irrigation at $k$ level must not exceed the maximum volume available:

$$
\begin{aligned}
& \sum_{i=1}^{n} x_{i 0} w_{i 0}-\sum_{i=1}^{n} \sum_{k=1}^{s} x_{i k} \Delta w_{i k} \leq V a \\
& \sum_{i=1}^{n} x_{10} w_{10}-\sum_{i=1}^{n} \sum_{k=1}^{s} x_{i k} \Delta w_{i k} \leq V m
\end{aligned}
$$


where, $\mathbf{W}_{\mathrm{m}}=$ total water depth applied during the growing season $\mathbf{i}$, at irrigation level $\mathrm{k}$, in $\mathrm{mm}$; $\mathbf{w m}$ $=$ monthly water depth applied to the culture 1 , at irrigation level $\mathbf{k}$, in $\mathbf{m m}$; $\mathbf{V a}=$ annual water volume available, in mm.ha; and $\mathrm{Vm}=$ monthly water volume available, in mm.ha.

(b) cropped area restriction for crop i:

$$
\mathbf{X}_{10} \leq \text { ou } \geq \mathbf{G}_{\mathbf{i}}
$$

where $G_{1}$ is the restricted cropped area (ha) for crop i.

(c) total planted area restricted to each month:

$$
\sum_{i=1}^{n} x_{10} \leq s_{m}, \text { for } m=1,2, \ldots, 12
$$

where $S_{m}$ is the total area available (ha) for the cropping in the month $\mathbf{m}$.

(d) the irrigated area with $\mathbf{W}_{\mathbf{k}}$ depth must not exceed the irrigated area with the depth for the maximum production:

$$
x_{\text {n. }}-x_{10} \leq 0, \text { for } i=1,2, \ldots, n
$$

(e) non-negativity:

$$
X_{10} \geq 0 \text { and } X_{1 k} \geq 0
$$

Application of the model: The model was applied to the Senator "Nilo Coelho" Irrigation Project, located in Petrolina - Brazil. The necessary coefficients to the model were obtained from Dantas Neto (1994). It is based on the data from the monitoring report of the agricultural year of 1992 of the 3rd Regional Superintendency of CODEVASF, in the report of the irrigation district of the Senator "Nilo Coelho" Irrigation Project. Data from the researches carried out in the region together with CPATSA-EMBRAPA and additional information from the mentioned institutions were also used.

The aim was to obtain an optimal pattern of irrigated crops compatible with the area exploration characteristics in such a way to maximize the net income of the project. The constraints were highlighted concerning the availability of water, soil and market.
In TABLE 1 are the most traditional crops of the Senator "Nilo Coelho" Project considered in the analyses performed in this paper. Their answer functions to water, seeding season, production costs without the water cost and the product price obtained in the agricultural year of 1992 according to Dantas Neto (1994), were also considered. Such crops represent an occupation of approximately $90 \%$ of the colonized area of this project, whose pattern of monthly occupation is shown on TABLE 2.

The project has 9,280 ha irrigated destinated to 1,427 settlers. Nowadays, the total area explored by the settlers with the proposed crops is of 7,424 ha. The remaining area is reserved to other crops such as mango and west indian cherry which have just been implanted.

The restrictions to the cropped area are the following:

(a) Phaseolus beans sown in September: minimum area $=714 \mathrm{ha}$; reason - internal consumption.

(b) Watermelon sown in February maximum area $=2,854$ ha; reason - market.

(c) Watermelon sown in October minimum area = 2,854 ha; reason - market.

(d) Annual area of watermelon in the project: maximum area $=4,281$ ha; reason - market.

e) Pepper sown in September: maximum area $=$ 2,141 ha; minimum area $=714$ ha; reason food processing capacity.

(f) Tomato sown in May: maximum area $=4,281$ ha; minimum area $=714 \mathrm{ha}$; reason food processing capacity and market.

(g) Anion sown in February maximum area = 357 ha; reason - farmers resistence to aspersion.

(h) Banana: maximum area $=2854 \mathrm{ha}$; minimum area $=714$ ha; reason - food processing capacity.

The crop water requirements during the growing season were estimated based on the production functions (TABLE 3). The monthly requirement was estimated giving the total irrigation depth in relation to maximum monthly 
evapotranspiration for each crop. The values are shown on TABLE 4 and expressed as percentage of the total depth during the season.

The Senator Nilo Coelho Irrigation Project was created to offer to its users a monthly water volume of $12,000,000 \mathrm{~m}^{3}$. However, due to operational problems, the maximum monthly volume offered was $9,861,040 \mathrm{~m}^{3}$ and the annual maximum was $66,644,500 \mathrm{~m}^{3}$, in the year of 1992. Such volumes were considered available to the developed model.

TABLE 1 - Characterization of the crops in the Senator "Nilo Coelho" Irrigation Project*.

\begin{tabular}{|c|c|c|c|c|c|c|}
\hline $1 * *$ & Crops & $\begin{array}{l}\text { Production function } \\
\text { Y(kg ha }) \text { e W (mm) }\end{array}$ & $\mathbf{R}^{2}$ & $\begin{array}{l}\text { Sowing } \\
\text { Season }\end{array}$ & $\begin{array}{c}P_{i} f_{1} \\
\text { (US } s / k g)\end{array}$ & $\begin{array}{c}\text { CA } \\
\text { (USS/ha) }\end{array}$ \\
\hline 1 & Phaseolus beans & $Y=8 \times 10^{-2} e^{\left(3.823 \times 10^{-2} W-3.508 \times 10^{-5} W^{2}\right)}$ & 0.99 & May & 0.58 & 450.00 \\
\hline 2 & Phaseolus beans & $Y=8 \times 10^{-2} e^{\left(3.823 \times 10^{-2} W-3.508 \times 10^{-5} W^{2}\right)}$ & 0.99 & September & 0.58 & 450.00 \\
\hline 3 & Viena beans & $Y=436.32 e^{\left(2.92 \times 10^{-3} \mathrm{~W}-1.622 \times 10^{-6} \mathrm{~W}^{2}\right)}$ & 0.78 & Jenuary & 0.54 & 400.00 \\
\hline 4 & Watermelon & $y=-2301.15+81.09 W-0.0457 W^{2}$ & 0.88 & February & 0.08 & 750.00 \\
\hline 5 & Watermelon & $Y=-2301.15+81.09 W-0.0457 W^{2}$ & 0.88 & October & 0.08 & 750.00 \\
\hline 6 & com & $Y=-8481.94-20.686 W+1151.92 W^{0.5}$ & 098 & May & 0.15 & 432.00 \\
\hline 7 & Com & $Y=-8481.94-20.686 W+1151.92 W^{0.5}$ & 0.98 & December & 0.15 & 432.20 \\
\hline 8 & Melon & $Y=6.0331 \times 10^{-2} W^{(3.6045-0.6065 \log W)}$ & 0.99 & Febnuary & 0.16 & 908.00 \\
\hline 9 & Pepper & $Y=9453.68 e^{\left(6.744 \times 10^{-4} W-4.4217 \times 10^{-7} W^{2}\right)}$ & 0.98 & September & 0.15 & 889.00 \\
\hline 10 & Tomato & $Y=-23000+271.9355 W-023948 W^{2}$ & 0.98 & May & 0.08 & 1645.00 \\
\hline 11 & Anion & $Y=-115910+378.924 W-0.2299 W^{2}$ & 0.62 & February & 0.20 & 1530.00 \\
\hline 12 & Banana & $Y=-36848+6325504 W-0.01097 W^{2}$ & 0.99 & -\# & 0.18 & 1200.00 \\
\hline
\end{tabular}

* - Source: Dantas Neto (1994); ** - An integer that represents the crop (i=1, 2, .., n); 1 - Production cost of the crop I, except the cost of the water, 1 - Product price; \# - The banana crop is considered in this study as the second year crop.

TABLE 2 - Cropping calendar for the Senator "Nilo Coelho" Irrigation Project.

\begin{tabular}{|c|c|c|c|c|c|c|c|c|c|c|c|c|}
\hline \multirow[t]{2}{*}{ Months } & \multicolumn{12}{|c|}{ Crops } \\
\hline & 1 & 2 & $\overline{3}$ & $\overline{4}$ & 5 & 6 & 7 & 8 & 9 & 10 & 11 & $\overline{12}$ \\
\hline JAN & & & $\bar{x}$ & & & & $\bar{x}$ & & & & & $\bar{x}$ \\
\hline FEB & & & $\mathrm{x}$ & $x$ & & & $\mathrm{x}$ & $\mathbf{x}$ & & & $\mathrm{x}$ & $\mathrm{x}$ \\
\hline MAR & & & $\mathrm{x}$ & $\mathrm{x}$ & & & $\hat{\mathbf{x}}$ & $\mathrm{x}$ & & & $\hat{\mathrm{x}}$ & $\mathrm{x}$ \\
\hline APR & & & & $\ddot{x}$ & & & & $\ddot{x}$ & & & $\mathrm{X}$ & $\mathrm{x}$ \\
\hline MAY & $x$ & & & & & $\mathrm{x}$ & & & & $x$ & & $\mathrm{x}$ \\
\hline$\pi N$ & $\mathrm{x}$ & & & & & $\mathrm{x}$ & & & & $x$ & & $\mathrm{x}$ \\
\hline JU & $\mathrm{x}$ & & & & & $\mathrm{X}$ & & & & $\mathrm{x}$ & & $\mathrm{X}$ \\
\hline AUG & & & & & & $\mathrm{x}$ & & & & $x$ & & $x$ \\
\hline SEPT & & $x$ & & & & & & & $x$ & & & $\mathrm{X}$ \\
\hline OCT & & $\mathrm{x}$ & & & $x$ & & & & $\mathrm{x}$ & & & $x$ \\
\hline NOV & & $\mathrm{x}$ & & & $\mathrm{x}$ & & & & $\mathrm{x}$ & & & $x$ \\
\hline DEC & & & & & $\mathrm{X}$ & & $\mathrm{X}$ & & $\mathrm{x}$ & & & $\mathrm{x}$ \\
\hline
\end{tabular}


TABLE 3 - Total water depths during the crop season at different irrigation levels used in the model.

\begin{tabular}{|c|c|c|c|c|c|c|c|c|c|c|c|c|}
\hline \multirow[t]{3}{*}{$k$} & \multicolumn{12}{|c|}{ Crops } \\
\hline & 1 & 2 & 3 & 4 & 5 & 6 & 7 & 8 & 9 & 10 & 11 & 12 \\
\hline & \multicolumn{12}{|c|}{ WATER DEPTHS (mm) } \\
\hline 0 & 545 & 545 & 500 & 887 & 887 & 775 & 775 & 940 & 763 & 568 & 824 & 2900 \\
\hline 1 & 540 & 540 & 495 & 860 & 860 & 760 & 760 & 920 & 740 & 560 & 820 & 3850 \\
\hline 2 & 530 & 530 & 485 & 830 & 830 & 740 & 740 & 900 & 710 & 550 & 815 & 2800 \\
\hline 3 & 510 & 510 & 475 & 790 & 790 & 700 & 700 & 880 & 680 & 540 & 805 & 2700 \\
\hline 4 & 490 & 490 & 460 & 750 & 750 & 650 & 650 & 850 & 650 & 520 & 790 & 2500 \\
\hline 5 & 470 & 470 & 440 & 700 & 700 & 600 & 600 & 800 & 600 & 500 & 750 & 2300 \\
\hline 6 & 450 & 450 & 420 & 650 & 650 & 550 & 550 & 750 & 550 & 480 & 700 & 2100 \\
\hline 7 & 420 & 420 & 390 & 550 & 550 & 500 & 500 & 650 & 500 & 460 & 625 & 1800 \\
\hline 8 & 390 & 390 & 360 & 450 & 450 & 450 & 450 & 500 & 450 & 430 & 550 & 1400 \\
\hline 9 & 350 & 350 & 330 & 350 & 350 & 350 & 350 & 350 & 400 & 400 & 475 & 1000 \\
\hline
\end{tabular}

TABLE 4 - Monthly crop water need expressed in percentage of the total depth during the season.

\begin{tabular}{|c|c|c|c|c|c|c|c|c|c|}
\hline \multirow{2}{*}{ Months } & \multicolumn{9}{|c|}{ Crops } \\
\hline & 1 e 2 & 3 & 4 e 5 & $6 \mathrm{e} 7$ & 8 & 9 & 10 & 11 & 12 \\
\hline$\overline{\text { JAN }}$ & & 27.71 & & 30.78 & & & & & 8.52 \\
\hline FEB & & 38.02 & 25.95 & 27.88 & 25.95 & & & 27.41 & 7.02 \\
\hline MAR & & 34.27 & 39.98 & 20.30 & 39.98 & & & 39.19 & 7.03 \\
\hline APR & & & 34.07 & & 34.07 & & & 33.40 & 6.65 \\
\hline MAY & 23.29 & & & 16.46 & & & 16.29 & & 6.80 \\
\hline JUN & 37.57 & & & 24.51 & & & 21.83 & & 6.59 \\
\hline JUL & 39.14 & & & 31.21 & & & 30.90 & & 7.62 \\
\hline AUG & & & & 27.82 & & & 30.98 & & 9.34 \\
\hline SEP & 23.40 & & & & & 17.13 & & & 10.27 \\
\hline OCT & 41.99 & & 28.32 & & & 25.15 & & & 11.06 \\
\hline NOV & 34.61 & & 39.89 & & & 29.17 & & & 10.13 \\
\hline DEC & & & 31.79 & 21.04 & & 28.55 & & & 8.97 \\
\hline
\end{tabular}

\section{RESULTS AND DISCUSSION}

Optimal Solution of the Model: In the SNCP, the highest annual water volume offered to the users was $66,664,500 \mathrm{~m}^{3}$ and the monthly volume was $9,861,040 \mathrm{~m}^{3}$, in 1992 . Using these water constraints and satisfying the maximum and minimum crop areas requirements, the proposed model resulted in the optimized crop planning, showed in the TABLE 5 . The Phaseolus beans crop was only indicated for sowing in September, with a 714 ha area, defined by the need of satisfying the internal consumption, with a recommended irrigation of $510 \mathrm{~mm}$. The watermelon sown in October has minimum (714 ha) and maximum (4281 ha) area constraints because of the market demand; the model predicted only the 714 ha crop, to satisfy the minimum need, with a $450 \mathrm{~mm}$ total water depth. The 714 ha pepper crop, recommended by the model, should receive a water supply of $400 \mathrm{~mm}$. To the tomato crop sown in May it was recommended an area of 3.082 ha with a water supply of $500 \mathrm{~mm}$. The onion crop area, irrigated with $790 \mathrm{~mm}$, was indicated in the maximum level, $357 \mathrm{ha}$, and the banana crop will occupy an $1,843 \mathrm{ha}$ area, with $2,100 \mathrm{~mm}$ water during the year. All crops should receive irrigation with 
deficit, and the recommended levels were those which resuited in the largest total net income.

Marginal cost associated with the non-basis crop activities: The crops which were not recommended, named non-basis variables in the model solution, have marginal costs, which are referred to the reduction of the net income by cultivated area unit. In TABLE 6 the marginal costs of the non-basis crop are showed, for irrigation, without water deficit. For example, the Phaseolus bean crop was not indicated for sown in May, and in this case, there is a marginal cost associated with this activity, that is, in each hectare of the crop sown in may and irrigated without deficit ( $545 \mathrm{~mm}$ ) will occur a reduction of US\$ $1,598.90$ in the net income.

In TABLE 6 the minimum income that each crop must result to be selected to cultivation are shown. For example, com should not be recommended while its contribution for profit is below US\$ 2,291.60/ha; Phaseolus beans sown in May can only participate in the optimal solution if the profit is above US $\$ 2,616.60 / \mathrm{ha}$. This crop, sown in September, represents a basic solution due to the need of cultivating a minimum area of $714 \mathrm{ha}$, to satisfy the internal demand.

The ideal solution of the model indicated the cultivation of the following crops, at the lower area limits (TABLE 5): Phaseolus beans sown in September (714 ha), watermelon sown in October (714 ha) and green pepper sown in September (714 ha), and also onion sown in February at the upper area limit (357 ha). These activities include the marginal costs (TABLE 7); for Phaseolus beans sown in September, the value is US\$ $1,598.90 / \mathrm{ha}$ (negative value), meaning that when cultivating one extra hectare of this crop, the total net income will be reduced by this amount. The same is valid for watermelon and green pepper. For onion the marginal cost was of US\$ 2,996.40 (positive value), indicating that the reduction of each hectare of this crop will reduce the total net income by this amount. It can also be observed that all available land was used $(7,424$ ha), resulting in a land shadow price of US\$ $1,115.20 / \mathrm{ha}$, corresponding to the expected net income reduction if this resource becomes more restrictive in one unit.

Sensitivity Analysis of the available water volume: TABLE 8 presents the volumes of water used during the year, at the respective months, considering the maximum annual availability of $66,644,500 \mathrm{~m}^{3}$, and the monthly one of $9,861,040$ $\mathrm{m}^{3}$. It can be observed that the annual availability in the SNCP represents of the effective constraint of the production system. The optimum cultivation pattern determined by the solution of the model resulted in a consumption of all available water. The monthly availability was not limiting. Since the annual volume is a scarce resource a shadow price value is associated, which corresponds to the expected reduction of the value of the object function in case this volume becomes more scarce in one unit. In this case, if the annual water availability is reduced by 1000 $\mathrm{m}^{3}$, the net income is reduced by US $\$ 281.60$.

On the other hand, the net income can be increased by the same value if $1000 \mathrm{~m}^{3}$ are added. In this way the shadow price of water represents the maximum value which the user could be willing to pay in order to have one additional unit of volume.

TABLE 5 - Optimal solution found by the LP model, to a available water volume of $66,644,500 \mathrm{~m}^{3}$.

\begin{tabular}{llccc}
\hline Variable & \multicolumn{1}{c}{ Crops } & Sowing time & Water depth (mm) & Area (ha) \\
\hline $\mathrm{X}_{23}$ & Phaseolus beans & September & 510 & 714.00 \\
$\mathrm{X}_{58}$ & Watermelon & October & 450 & 714.00 \\
$\mathrm{X}_{99}$ & Pepper & September & 400 & 714.00 \\
$\mathrm{X}_{105}$ & Tomato & May & 500 & 308.00 \\
$\mathrm{X}_{114}$ & Onion & February & 790 & 357.00 \\
$\mathrm{X}_{126}$ & Banana & $* * * * * *$ & 2100 & $1,843.00$ \\
\hline Net income & US $\$ 25,061,420.11$ & & & \\
\hline
\end{tabular}


TABLE 6 - Marginal costs associated to non-basis activities and minimum contribution value to profit, for an annual volume of available water of $66,644,500 \mathrm{~m}^{3}$ and irrigation with no deficit.

\begin{tabular}{llccc}
\hline Variable & Crops & Sowing time & $\begin{array}{c}\text { Marginal cost } \\
\text { (US\$/ha) }\end{array}$ & $\begin{array}{c}\text { Minimum contribution to profit } \\
\text { (US\$/ha) }\end{array}$ \\
\hline $\mathrm{X}_{10}$ & Phaseolus beans & may & $1,598.90$ & $2,616.60$ \\
$\mathrm{X}_{30}$ & Vigna bean & January & $1,978.60$ & $2,175.30$ \\
$\mathrm{X}_{40}$ & Watermelon & February & $1,209.00$ & $3,011.00$ \\
$\mathrm{X}_{60}$ & Com & May & $1,714.30$ & $2,291.60$ \\
$\mathrm{X}_{70}$ & Corn & December & $1,714.30$ & $2,291.60$ \\
$\mathrm{X}_{80}$ & Melon & February & $1,369.20$ & $2,499.20$ \\
\hline
\end{tabular}

TABLE 7 - Marginal costs associated with the activities with area restrictions, which solution is the upper or lower limit of the restriction.

\begin{tabular}{lcccc}
\hline Crop & Sowing time & $\begin{array}{c}\text { Area constraint } \\
\text { (ha) }\end{array}$ & $\begin{array}{c}\text { Usage } \\
\text { (ha) }\end{array}$ & $\begin{array}{c}\text { Marginal cost } \\
\text { (US\$/ha) }\end{array}$ \\
\hline Phaseolus beans & September & $\geq 714$ & 714 & $-1,598.90$ \\
Watermelon & October & $\geq 714$ & 714 & $-1,211.00$ \\
Green pepper & September & $\geq 714 \mathrm{e} \leq 2,141$ & 714 & $-1,464.20$ \\
Onion & February & $\leq 357$ & 357 & $2,996.40$ \\
\hline Total area & & $\leq 7,424$ & 7,424 & $1,115.20^{*}$ \\
\hline
\end{tabular}

* land shadow price.

TABLE 8. Used Annual and Monthly water volumes and opportunity costs.

\begin{tabular}{|c|c|c|c|c|c|c|}
\hline $\begin{array}{l}\text { Constraint } \\
\text { (water) }\end{array}$ & Status & $\begin{array}{l}\text { Usage } \\
\left(\mathrm{m}^{3}\right)\end{array}$ & $\begin{array}{l}\text { Slack } \\
\left(\mathrm{m}^{3}\right)\end{array}$ & $\begin{array}{l}\text { Shadow price } \\
\left(\mathrm{US} \$ / 1000 \mathrm{~m}^{3}\right)\end{array}$ & $\begin{array}{c}\text { Minimum } \\
\text { volume } \\
\left(\mathrm{m}^{3}\right)\end{array}$ & $\begin{array}{c}\text { Maximum } \\
\text { volume } \\
\left(\mathrm{m}^{3}\right)\end{array}$ \\
\hline Annual & binding & $66,644,500$ & 0 & 281.60 & $48,579,700$ & $82,819,700$ \\
\hline January & non binding & $3,297,954$ & $6,563,046$ & 0 & $3,297,954$ & $* * *$ \\
\hline February & non binding & $3,490,584$ & $6,370,416$ & 0 & $3,490,584$ & $* * *$ \\
\hline March & non binding & $3,826,428$ & $6,034,572$ & 0 & $3,826,428$ & *** \\
\hline April & non binding & $3,516,465$ & $6,344,535$ & 0 & $3,516,465$ & $* * *$ \\
\hline May & non binding & $5,142,124$ & $4,718,876$ & 0 & $5,142,124$ & $* * *$ \\
\hline June & non binding & $5,914,177$ & $3,946,823$ & 0 & $5,914,177$ & $* * *$ \\
\hline July & non binding & $7,851,362$ & $2,009,638$ & 0 & $7,851,362$ & $* * *$ \\
\hline August & non binding & $7,530,388$ & $2,330,612$ & 0 & $7,530,388$ & $* * *$ \\
\hline September & non binding & $5,315,061$ & $4,545,939$ & 0 & $\$, 315,061$ & $* * *$ \\
\hline October & non binding & $7,436,525$ & $2,424,475$ & 0 & $7,436,525$ & $* * *$ \\
\hline November & non binding & 7,295,739 & $2,565,262$ & 0 & $7,295,739$ & *** \\
\hline December & non binding & $5,307,281$ & $4,553,719$ & 0 & $5,307,281$ & **** \\
\hline
\end{tabular}


The maximum and minimum volumes of water (TABLE 8) represent the limits of water availability for which the shadow price is valid and the optimum solution is not altered, they can, however, modify the cultivated areas. For example, the annual water availability is allowed to vary between $48,579,700 \mathrm{~m}^{3}$ and $82,819,700$ $\mathrm{m}^{3}$ without change of the shadow price and the optimal solution. The lower limits of monthly availability are shown. For example, in May, volumes greater than $5.142 .124 \mathrm{~m}^{3}$ allow the soluction to maintain the same optimum value and a shadow price of zero. It can also be noted that July, August, October and December present the greatest lower limits, showing that in these months the consumption was greater.

Sensitivity analysis of the basic variables marginal net income: In general, it is possible to have variation in the net marginal income of a basic activity, without change of the optimal levels in the solution. TABLE 9 presents the allowed variation intervals for the net marginal income of the basic variables found in the optimum solution of the problem, who's limits are identified by maximum and minimum marginal incomes and the values found in the model, identified as actual. It can be seen that Phaseolus beans sown in September and irrigated with of $510 \mathrm{~mm}$ of water, will stay at the base, with $714 \mathrm{ha}$, even it its marginal net income varies between US\$ $945.89 / \mathrm{ha}$ and US\$ $2551.52 / \mathrm{ha}$. If the value is bellow US\$ $945.89 / \mathrm{ha}$ the area will stay on 714 ha since it is the lower limit of the restriction, however, a water depth smaller than $530 \mathrm{~mm}$ might be recommended. A similar analysis can be made for water meion.

Green pepper irrigated with $400 \mathrm{~mm}$ (minimum water depth) can yield any value of the net marginal income lower than US\$ $2,241.42 / \mathrm{ha}$ and will stay at the base with 714 ha. If its marginal net income is above US\$ $2,241.42 / \mathrm{ha}$ an increase in cultivated area could be indicated, or an increase of irrigation water depth. Tomatoes, with the restriction 714 ha $\leq$ cultivated area $\leq 4,281 \mathrm{ha}$, were indicated with an area of 3082 ba and a water depth of $500 \mathrm{~mm}$. At this irrigation level, the marginal net income can vary between US\$ $2,516.00 / \mathrm{ha}$ and US $\$ 2,754.00 / \mathrm{ha}$ without change of the optimum solution. Lower values of the net income could lead to smaller irrigation water depths, once the area cannot be smaller than 714 ha. Higher values lead to an increase in area and/or irrigation water depth. Onion should be cultivated on an area of 357 ha (upper restriction limit) and water depth of 790 $\mathrm{mm}$, for any value of the upper marginal net income of US\$ 6,327.41/ha. Its area and/or waterdepth could be smaller only if the net income would be lower than this value. For banana, an area of 1,843 ha and an irrigation depth of 2,100 $\mathrm{mm}$ are the optimum solution while the marginal net income varies between US\$ 6,977.46/ha and US\$7,034.96/ha. Lower incomes will lead to lower area and/or irrigation water depth, and higher values will increase these values up to the limits of the restrictions.

Analysis of the annual available water volume: Making an analysis of the availability of water of the SNCP it was observed that for values bellow $17,850,000 \mathrm{~m}^{3}$, the solution of the PL model was infeasible, indicating that the model constaints are not satisfied, specifically those that limit the minimum cultivated area. For equal or greater volumes, the solution is a feasible basic solution.

For annual volumes below $88,338,983$ $\mathrm{m}^{3}$ maintaining the maximum monthly volumes of $9,861,040 \mathrm{~m}^{3}$, the model shows a complete use of these resource in the optimal solution (Figure 1), resulting in a shadow price for each volume (Figure 2). Volumes greater than this represent an excess and, therefore, a shadow price equal to zero. In Figure 1, it can be observed that the net income of the project increases as a function of the increase of annual water availability. The obtained value, however, depends on the monthly available water. For a monthly value of $9,861,040$ $\mathrm{m}^{3}$, the net income stabilized in US $\$ 30,475,617.64$ for annual volumes equal or greater than $88,338,983 \mathrm{~m}^{3}$.

The shadow price is valid between certain limits of available resources, which are indicated in Figure 2. It can be observed that when the volume of available water is between $17,850,000$ and $20,527,500 \mathrm{~m}^{3}$, the shadow price presents its largest value (US\$819.10/1,000 $\mathrm{m}^{3}$ ). The lowest shadow price (US $\$ 4.00 / 1,000 \mathrm{~m}^{3}$ ) will occur if the project have the capacity of offering a volume of water between $88,324,703$ and $88,338,983 \mathrm{~m}^{3}$. Higher values will have a shadow price of zero. In a situation with greater water availability, crops of lower return per unit area are irrigated in such a way that an increase in net income per additional unit of water will decrease. 
TABLE 9 - Sensitivity analysis of the basic variables marginal net income.

\begin{tabular}{clccc}
\hline & & \multicolumn{3}{c}{ Marginal net income (US\$/ha) } \\
\hline Variable & \multicolumn{1}{c}{ Crop } & Minimum & \multicolumn{1}{c}{ Actual } & Maximum \\
\hline $\mathrm{X}_{23}$ & Phaseolus beans & 945.89 & 952.62 & $2,551.52$ \\
$\mathrm{X}_{58}$ & Water melon & $1,156.36$ & $1,170.80$ & $2,381.86$ \\
$\mathrm{X}_{99}$ & Green pepper & $* * *$ & 777.25 & $2,241.42$ \\
$\mathrm{X}_{105}$ & Tomato & $2,516.00$ & $2,552.96$ & $2,754.00$ \\
$\mathrm{X}_{114}$ & Onion & $6,327.41$ & $6,335.24$ & $* * *$ \\
$\mathrm{X}_{126}$ & Banana & $6,977.76$ & $7,028.00$ & $7,034.96$ \\
\hline
\end{tabular}

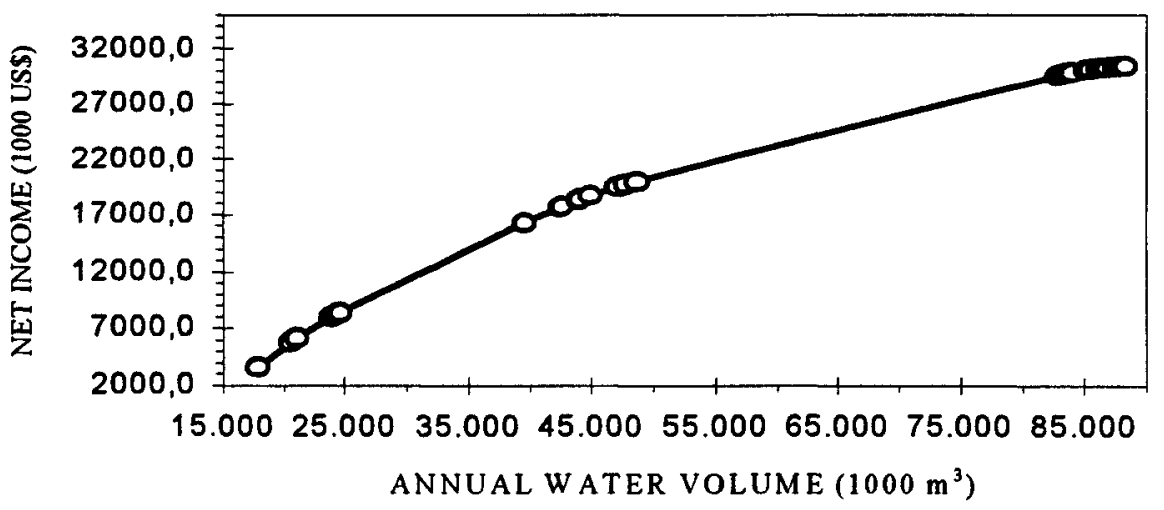

Figure 1 - Net income of SNCP as a function of the annual available volume of water, for a monthly volume of $9,861,040 \mathrm{~m}^{3}$

In the SNCP, the largest volume of water offered to the users was $66,649,500 \mathrm{~m}^{3}$ in 1,992 . With this volume, the increase of the net income per unit of additional volume is US $\$ 281.60 / 1,000 \mathrm{~m}^{3}$. This value corresponds to the shadow price of water for volumes between $48,579,700$ and $82,819,700 \mathrm{~m}^{3}$. If this is the average volume that the project can offer, and having intention of investing in capital to improve water use efficiency and increase water availability, the investment will be worthwhile if it reaches per unit volume, the maximum value equal to its shadow price. The misuse of water implies in a shadow price equal to the sacrificed net income per unit of water which is not used.
The official price of water in the SNCP in 1992 was $\$ 16.00 / 1,000 \mathrm{~m}^{3}(5.68 \%$ of the shadow price of the available volume for that year). At this relation, it is possible that users will use more water than necessary. In projects where water is a scarce resource, differential water prices should be adopted, so that users consuming amounts of water above average, would pay a price close to the shadow price.

This proposal is in agreement with Palacios Velez $(1,976)$, who studied strategies to improve water management in the Sonora District, in Mexico. 
Consideration on the model and its use: The farmers water demand curve was obtained according to a methodology based in several hypotheses with limitations. Initially, it was established that when the water availability is small, the irrigation project users will implement first the crops with greater incomes. As the water availability increases, crops with lower incomes will be used. So, the obtained demand curve assumes that the water and others resources usage is done efficiently. However, the technological level among the users is variable, so, with the same water volume, different farmers will have different net incomes.

Another limitation of the model concerns the uncertainty to which the farmer is subjected. The objective function considered herein admits a given structure of income and costs. Either the incomes and the costs are subjected to variations, hence it is not possible to guarantee a fixed price of the products and inputs.

One solution for these problems would be to include in the model probability elements in order to consider risk factors. The main approaches for these models can be derived in two groups, according to the treatment given to the source of uncertainty. In the first group, the only uncertainty source is related to the net income per unit of each production alternative. In this case, the primary uncertainty source (marginal net income, prices and costs) are coupled to one single risk component, expressed in the objective function of the models. In the second group, are the approaches that include in the mathematical models the randomicity of the technical coefficient of the restrictions, and levels of available resources. This approach is generically called stochastic programming. In any case, the modeling is very complex, requiring time series of information which, usually, are not available.

Concerning the labour problem, also considered of influence in case studies, effects on the shadow price can be expected. The lowers the labor power availability, due to difficulties in hiring or to the small number of family numbers, the lower will be the price which the farmer could be willing to pay for water use. This is due to the fact that having low labor power, cultivated area could be decreased and consequently, the net income of this land parcel implying in a lower availability of resources for water payment.

In any way, comparing the value which the farmer could be willing to pay for in irrigation water, with the price charged in the PSNC, it is observed that the shadow price given by the water demand curve is much higher than the charged price and, therefore, one has a great margin to be absorbed between these two values. It remain to the known if the charged price is based on investment and operational costs, or if there is some type of subsidy to the taxes charged to the user of the service. The water rate subsidy is only justified when the calculated rate is higher than the shadow price. Being the government a monopoly in the offer of this service for irrigation, there is no justification not to charge the water based on the demand curve.

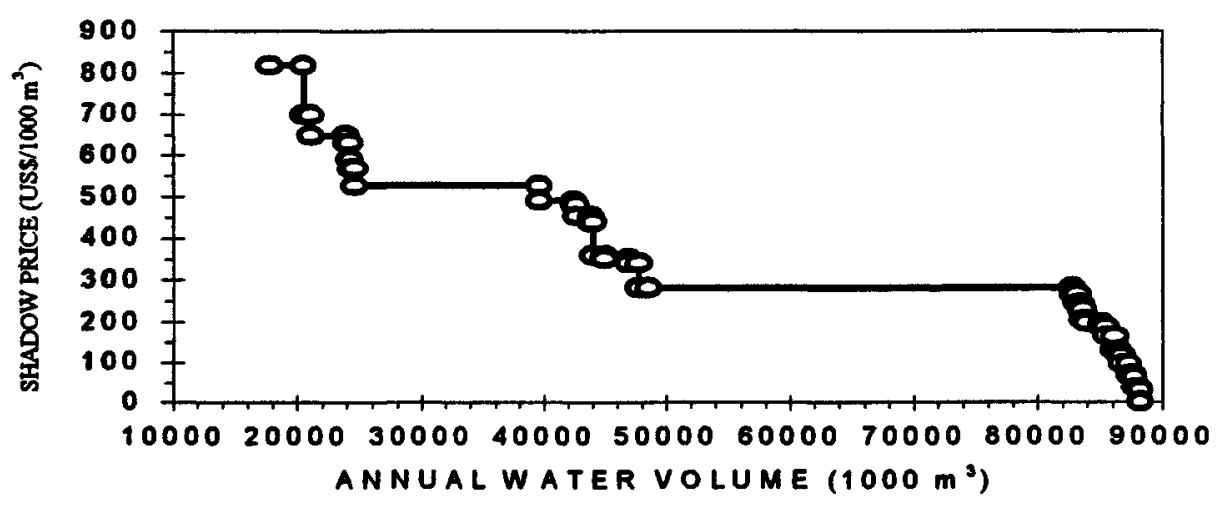

Figure 2 - Dual value of water as a function of the annual available volume for a monthly volume of $9,861,040 \mathrm{~m}^{3}$. 


\section{CONCLUSIONS}

a) the model was suitable for the management of the SNCP, resulting in optimal cropping patterns and showing the water requirements;

b) for $7,424 \mathrm{ha}$ of land and $66,644,500 \mathrm{~m}^{3}$ of water available on a year base, the opportunity cost of these resources were respectively, US\$ $1,115.20 / \mathrm{ha}$ e US\$ $281.60 / 1000 \mathrm{~m}^{3}$;

c) for the total monthly water availability of $9,861,040 \mathrm{~m}^{3}$, the total annual water availability of $66,644,500 \mathrm{~m}^{3}$ became an effective restriction to the increase of the net income of production system in the SNCP;

(d) maintaining the total monthly water availability of $9,861,040 \mathrm{~m}^{3}$, anual volumes lower than $88,338,983 \mathrm{~m}^{3}$ were used fully to reach the optimal solution, and that higher volumes than this limit, did not increase the net income;

(e) the optimization model estimated a net income of $52.34 \%$ higher than the traditional cropping pattern used in the SNCP, considering the agriculture year of 1992 .

\section{REFERENCES}

DANTAS NETO, J. Modelos de decišo para otimizagåo do padrăo de cultivo em áreas irrigadas, baseados nas funçóes de resposta das culturas a ígua. Botucatu, 1994. 125p. Tese (Doutorado) - Faculdade de Ciências Agronômicas, Universidade Estadual Paulista.

DOORENBOS, J.; KASSAN, A H. Yleld response to water. Roma: FAO, 1979. 193p. (Irrigation and Drainage Paper, 33).

ENGLISH, M.J. Deficit irrigation. I: Analitical framework. Journal of the Imrigation and Drainage Engineering, v.116, n.3, p.399-412, 1990.
ENGLISH, M.J.; NUSS, G.S. Designing for deficit irrigation. Journal of the Irrigation and Drainage Engineering, v.108, n.2, p.91-106, 1982.

HARGREAVES, G.H.; SAMANI, Z.A. Economics considerations on deficit irrigation. Journal of the Irrigation and Drainage Engineering, v.110, n.4, p.343-258, 1984.

HART, W.E.; NORUM, D.I.; PERI, G. Optimal seasonal irrigation aplication analysis. Journal of the Irrigation and Drainage Division, v.106, n.3, p.221-235, 1980.

KUMAR, R; KHEPAR, S.D. Decision models for optimal cropping patterns in irrigations based on crop water production functions. Agriculture Water Manngement, v.3, n.1, p.65-76, 1980.

McMILlaN Jr., C. Mathematical Programming: An introduction to the design and application of optimal decision machmes. New York: John Wiley, 1970. 495p.

MANNOCCHI, F; MECARELLI, P. Optimization analysis of deficit irrigation systems. Journal of the Irrigation and Drainage Engineering, v.120, n.3, p.484-503, 1994.

PALACIOS-VELEZ, $H$. Response functions of crops yield to soil moisture sterss. Water Resource Bulletin, $v$. 17, n.4, p.699-703, 1981.

PALACIOS-VELEZ, H. Strategies to improve water managment in Merican irrigation districts: A case andy in Sonorn. Tucson, 1976. 197p. Thesis (Ph.D.) - University of Arizona.

VAUX Jr., H.J.; PRUTTT, W.O. Crop-water production functions. In: HILLEL, D., ed.. Advances in Irrigation. New York: Academic Press, v.2, 1983. p.61-97.

Recebido para publicação de 20.04 .97 Aceito para publicação de 22.05 .97 